\title{
Det psykiatriske arbejde i Dansk Forsorgsselskab
}

\author{
Af overlæge FINI SCHULSINGER.
}

Følgende oplysninger og betragtninger vedrører i det væsentlige virksomheden ved Dansk Forsorgsselskabs centralkontor i K $\phi$ benhavn. Her begyndte det psykiatriske arbejde i 1951 med nuværende overlæge $B$. Borup Svendsens rent rådgivende virksomhed. I 1953 måtte man skifte psykiater og ansætte dr. Ellen Eriksen, der fast, een gang ugentligt dels havde konsultativt arbejde for kontoret, dels tog sig personligt af nogle af klienterne. Fraset den meget snævre tidsmæssige ramme, var ordningen i sin form og virkning tilfredsstillende. I 1957 måtte man påny skifte psykiater, og i dr. Kodahls tid steg kontakten mellem lægen og klienterne meget betydeligt. I foråret $1959 \mathrm{blev}$ dr. Kodahl afløst af undertegnede, og det lægelige arbejde havde nu et sådant omfang, at det blev n $\varnothing$ dvendigt at udbygge selskabets lægekonsultation, bl. a. efter forhandlinger med Den almindelige danske Lægeforening. Udbygningen er foregået i flere tempi, og lægearbejdet er efter min afgang fra selskabet (oktober 1962) organiseret på følgende måde: Mandag, onsdag og fredag er der åben konsultation fra kl. 15-18, hver gang varetaget af en psykiatrisk speciallæge, hvis arbejdstid er fra kl. 15-20, idet der kræves tid til at afvikle de fremm $\phi$ dte klienter, til skriftligt arbejde og til afsluttende konference vedr $\phi$ rende forholdsregler over for klienter, som enten er udeblevet eller som ved konsultationen har frembudt særlige problemer. På disse 3 åbne konsultationsdage bistås psykiateren i nogle af timerne af en yngre læge, således at større ophobning af klienter i venteværelset som regel undgås. Tirsdag og torsdag har to af de tilknyttede speciallæger i psykiatri en såkaldt lukket konsultationsdag, hvor noget af tiden bruges til konference med de sagsbehandlende forsorgsmedarbejdere og med personalet fra unders $\phi$ gelsesafdelingen, mens resten af tiden bruges til specielle psykoterapeutiske opgaver og andre lægelige opgaver, hvortil klienterne tilsiges på klokkeslet, og hvortil der er afsat den forn $\varnothing$ dne tid. Der er således læger til stede i selskabet 5 af ugens eftermiddage, hvilket medfører en særlig fordel for de forsorgsmedarbejdere, som udsættes for pludselige, dramatiske begivenheder med klienterne. Som forholdene er nu, forekommer det lægelige arbejde mig at

1) I let ændret form holdt som foredrag ved Dansk Forsorgsselskabs repræsentantskabsm $\varnothing$ de 16. oktober 1962.

$\left.{ }^{2}\right)$ Afdelingsleder Grethe Oehlenschlæger bedes modtage min bedste tak for sit arbejde med at fremskaffe de talmæssige oplysninger. 
foregå sagligt forsvarligt og tilfredsstillende. Der er blevet mere tid til rådighed for de enkelte konsultationer, og kun få klienter har med rette kunnet beklage sig over lang ventetid eller samlebåndsbehandling. Som det vil fremgå af det følgende, er ordningen $\mathrm{i}$ og for sig kun insufficient med henblik på etablering af grundig, længerevarende psykoterapi.

Den lægelige virksomhed har desværre ikke været tilrettelagt med henblik på en videnskabelig vurdering af resultaterne, men det er dog muligt på nuværende tidspunkt at fremkomme med visse betragtninger og at g $\phi \mathrm{re}$ en art status.

Hovedparten af klienter med vilkår om lægelig behandling udg $\varnothing$ res af alkoholister. Disses vilkår er nu som regel formuleret som et vilkår om lægelig afvænningsbehandling for spiritusmisbrug, hvilket er en fordel frem for den ofte tidligere anvendte, noget rigide bestemmelse om antabusbehandling. Af tabel nr. 1

\section{Tabel 1.}

Behandlingssted for klienter med vilkår om alkoholistbehandling ved Centralkontoret $i 1961$.

Selskabets konsultation 104 klienter

Justitsministeriets psykiatriske klinik ............ 14

Ungdomskliniken, Læss $\varnothing$ esgade ................ 6

Ambulatoriet, Kommunehospitalet $\ldots \ldots \ldots \ldots \ldots \ldots \ldots$. 5

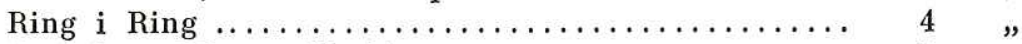

Ørsholt og Tåstrup Kurhjem $\ldots \ldots \ldots \ldots \ldots \ldots \ldots \ldots . \ldots, 3$ ",

Privat psykiater $\ldots \ldots \ldots \ldots \ldots \ldots \ldots \ldots \ldots \ldots \ldots \ldots \ldots \ldots \ldots \ldots \ldots, 1$ klient

Uden behandling (ophold på Brøndbyhus, sejler, sol-

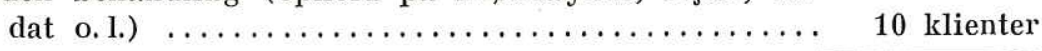

Samlet antal klienter med vilkår om afvænningsbehand-

ling for spiritusmisbrug $\ldots \ldots \ldots \ldots \ldots \ldots \ldots \ldots \ldots, 147$ klienter

fremgår det, at selskabets centralkontor i 1961 havde ansvar for 147 klienter med vilkår om afvænningsbehandling for spiritusmisbrug. Tallet dækker både de i 1961 tilkomne, samt de i 1961 behandlede, hvis vilkår var af ældre dato.

Af tabel 2 fremgår, at selskabet i samme år havde ialt 121 klienter med andre vilkår om lægelig behandling.

I tabel 3 har man fors $\phi$ gt at dele de 59 klienter, som modtog deres psykiatriske behandling i selskabets lægekonsultation, op efter kriminalitetens art, men på en lidt mere detailleret måde end det er muligt ved hjælp af straffelovsparagrafferne.

Af tabellerne vil man kunne forstå, at klientellet er af en meget varierende art. I alkoholistgruppen findes der ikke mange 
Tabel 2.

Behandlingssted for klienter med vilkår om psykiatrisk behandling ved Centralkontoret $i 1961$.

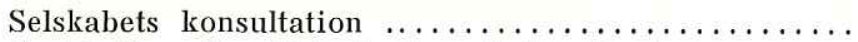
59 klienter

Sankt Hans hospital (incl. ambulatorium)

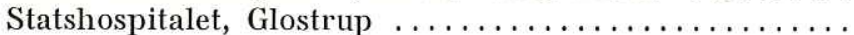

Justitsministeriets psykiatriske klinik 27

Filadelfia

Diverse statshospitaler på skift

Ungdomskliniken, Læss $\varnothing$ esgade

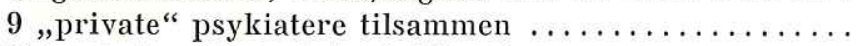

Uden behandling af forskellige årsager

"

3 ,

5 ,

1 klient

Samlet antal klienter med vilkår om psykiatrisk be-

handling

121 klienter

uden sociale problemer, som selskabet må løse samtidigt med den lægelige afvænningsbehandling. Blandt de andre psykisk afvigende kriminelle, er de sociale problemer af et betydeligt mere vekslende omfang, og en del af de sexuelt afvigende og kleptomane kan betegnes som i $\phi$ vrigt socialt veltilpassede.

Afhængigt heraf er den lægelige behandlingsform i forskellig griad knyttet sammen med forsorgs- og tilsynsarbejdet. Selskabets lægelige konsultation kan med rette betegnes som en sociallægelig institution, hvis virksomhed har træk tilfælles med arbejdet i m $\phi$ drehjælpsinstitutionerne, forvaringsanstalterne, sociallægeinstitutionen i Århus og forskellige, specielle alkoholkliniker.

Det er den i team'et bedst egnede person, som leder behandlingen i det enkelte tilfælde.

For mange af alkoholisternes vedkommende betyder det, at lægens rolle er ret sekundær i forhold til forsorgsmedarbejderens. Denne har kontakt med familien og med arbejdspladser, og derfor også meget hyppigt med klienten selv. Lægens rolle bliver i sådanne tilfælde at iværksætte afvænningsbehandlingen, lejlighedsvis at kontrollere den og ellers at være til rådighed for klienten, når der er særlige problemer. Vigtigst er det dog, at lægen jævnligt er til rådighed for forsorgsmedarbejderen, der må sikre sig, at den sociale plan ikke strider mod, hvad klientens øjeblikkelige habitus eller legemlige tilstand tillader.

Et sådant teamarbejde kan kun lykkes, når team'ets medlemmer er på god og fortrolig fod med hverandre. Alene af denne grund finder jeg det betænkeligt at henlægge alkoholistarbejdet til institutioner, som ikke forsorgsmæssigt er udstyret med sindelag, erfaring og kapacitet til at tage sig af det særlige kriminelle klientel, for hvilket så meget står på spil. 
Tabel 3.

Kriminalitetsform for de 59 klienter $i$ psykiatrisk behandling ved Centralkontorets lægekonsultation $i 1961$.

Kriminalitetsform

Underslab:
Kvinde

1

Mænd

$\begin{array}{ll} & 54 \\ 1 & 38 \\ 1 & 44\end{array}$

Vekselfalsk:

Dokumentfalsk:

Bedrageri :

Checkbedrageri:

Samlejetyveri:

Brugstyveri:

1

1

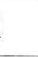

(20)

$\sqrt{2}+1$

1

$1-20$

Tyveri på arbejdspladsen:

Vold mod hustin:

Vold mod hustru:
Drabsfors $\oint$ :

Drab:

Almindeligt tyveri:

(herunder kleptomani)

$\begin{array}{ll}1 & 20 \\ 1 & 30 \\ 1 & 45 \\ 1 & 20 \\ 1 & 38 \\ & 41 \\ & 38 \\ & 38 \\ 1 & 29 \\ & 24 \\ & 22 \\ & 24\end{array}$


Kriminalitetsform Kvinder Mænd

Alder i år Ialt Overført

\begin{tabular}{lll}
6 & 6 & 52 \\
& 1 & 46 \\
1 & & 30 \\
1 & & 22 \\
& 1 & 19 \\
& 1 & \\
\hline 8 & 9 &
\end{tabular}

Receptfalsk:

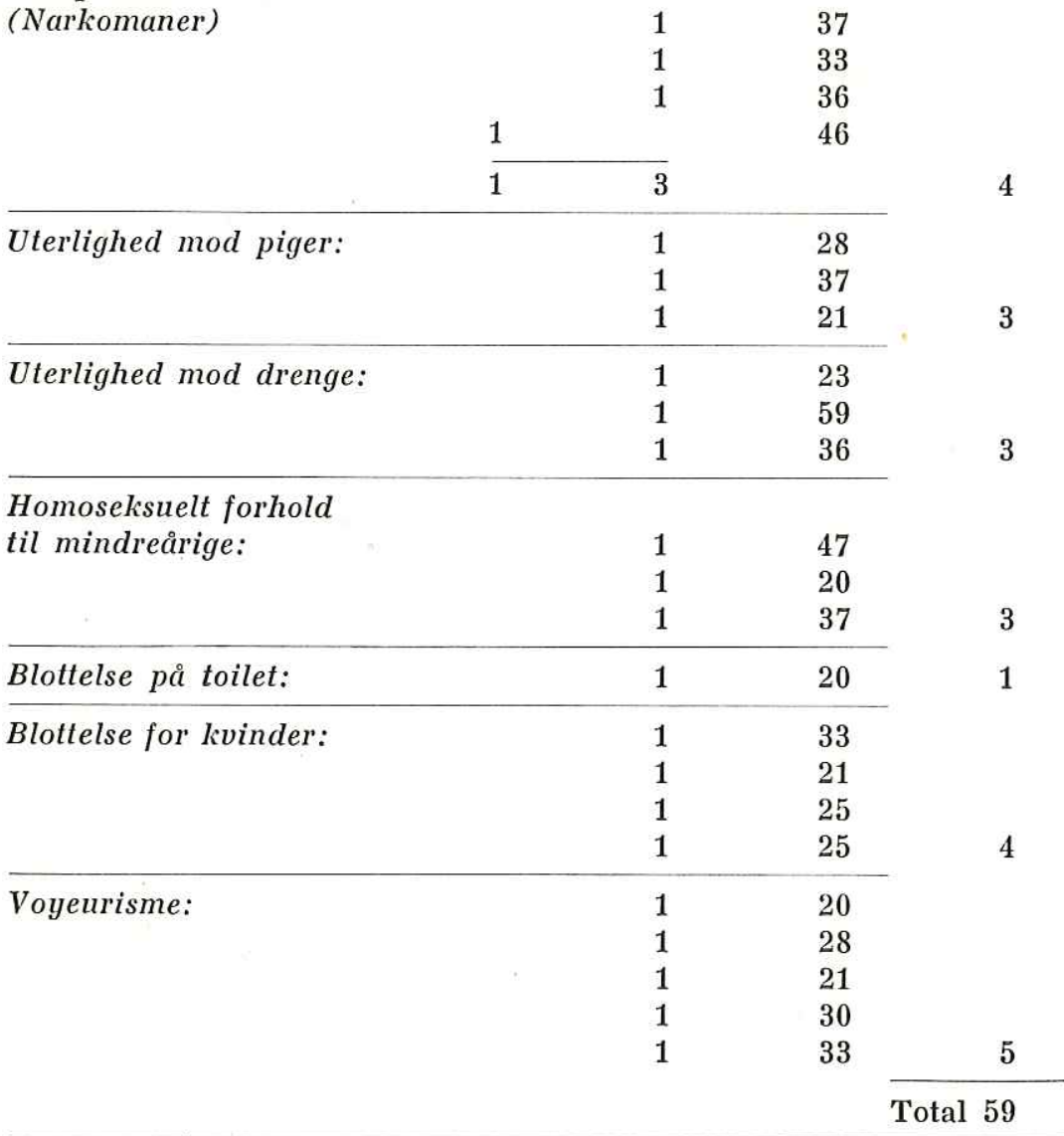

Alkoholisterne lægger med andre ord i vekslende grad beslag på selskabets lægelige arbejdskraft. I mange tilfælde går resocialiseringen glat, i andre tilfælde går den glat i en periode, men det kan da vise sig, at psykiateren, når det pludselig går nedad med klienten, kan diagnosticere specielle psykiske afvigelser som 
årsag hertil. Jeg tænker især på de svære, såkaldte dysforier, der ligger bag mange tilfælde af alkoholistiske tilbagefald.

Dysforier kan karakteriseres som anfald af depressive forstemninger kombineret med stærk ulystf $\phi$ lelse, ængstelse og subjektive eller objektive tegn på aggressivitet. Dysforier provokeres ofte af uheld og forurettelser, men undertiden synes de at komme af sig selv. Dysforier kendes i svagere eller stærkere grad af en større del af menneskeheden, men når de rammer karaktersvage eller psykopatiske personer, mødes de af en uimodståelig trang til $\phi$ jeblikkelig afspænding eller udladning, som normale eller neurotikere kan beherske i de dage eller timer dysforien varer. Alkohol i store kvanta kan ofte medf $\phi r e$ en afspænding, men desværre også de velkendte sociale komplikationer - og så er spillet gående.

Psykiaterens opgave er dels at påvise dysforiens rolle over for den enkelte og at påvirke den enkelte til at prøve at udholde den. Endelig kan psykiateren også mildne den ved hjælp af specielle medikamenter.

I et vist antal tilfælde kan psykiateren hjælpe alkoholisten gennem også at inddrage ægtefællen i behandlingen, hvorved ægtefællens holdning over for klienten undertiden kan blive mere hensigtsmæssig. Det kan dreje sig om holdning til drikkeriet, til sexuelle vanskeligheder eller f. eks. til svigerfamiliekonflikter.

I langt de fleste tilfælde indledes afvænningsbehandlingen med en antabuskur, der så vidt muligt gøres kontrolleret. Hvor det sk $\varnothing$ nnes heldigt og muligt foretages kontrollen af ægtefælle eller forældre, som samarbejder med den tilsynsførende. Hos meget enlige klienter eller i meget hårdnakkede tilfælde foregår kontrollen ved, at klienten møder frem i selskabet 2-3 gange ugentlig til antabusindtagelse.

Til de klienter, som har overbevisende tilfælde af bivirkninger under antabusbehandling (træthed, sexuelle potensforstyrrelser, smags- eller ford $\varnothing$ jelsesforstyrrelser m. m.) fors $\varnothing$ ger man nu med et andet præparat, Dipsan (Temposil) som er blottet for bivirkninger, men desværre har den ulempe, det skal indtages dagligt.

Bevæger vi os bort fra alkoholisterne og ser på de andre psykisk afvigende kriminelle, bliver de psylkoterapeutiske problemer noget mere komplicerede. Den i psykiatrisk henseende enkleste gruppe udg $\phi$ res af de, som er egentlig sindssyge; men gruppen er ikke stor, og en væsentlig del af den behandles i Sankt Hans hospitals efterbehandlingsambulatorium. Selskabets konsultation behandler dog nogle, såvel manio-depressive som schizofrene, og behandlingen former sig stort set som i ethvert andet psykiatrisk ambulatorium, nemlig som en kontrol af den medikamentelle behandling samt hospitalsindlæggelse ved tilbage- 
fald. Kombinationen med tilsynsarbejdet er dog også her værdifuld. Der står meget på spil for disse klienter på grund af det kriminelle mønster i tilslutning til sindslidelsen, og selskabet er vel bedre rustet end andre organisationer til at gribe ind i tide. Iøvrigt har det også en almen menneskelig værdi og rent sociale fordele at et tilbagefald hurtigst muligt kommer under behandling.

Narkomangruppen, der i tabellerne figurerer under receptfalsk, er svær at hjælpe, men også her giver kombinationen af læge og forsorgsmedarbejder en større chance for at gribe ind i tide.

Blandt de psykisk afvigende klienter lider nogle af organiske nervelidelser - især epilepsi eller følger af hjerneskader. De psykoterapeutiske muligheder er her begrænsede, og det er ofte psykiaterens vigtigste opgave at forklare forsorgsmedarbejderne, hvad sagen drejer sig om rent lægeligt, og hvor meget eller hvor lidt man kan forvente af den pågældende klient. Nogle af epileptikerne er så karakterforandrede, at de aldrig passer behandlingen på specialambulatorier for epilepsi, hvorfor selskabets læger i det mindste $\mathrm{i}$ perioder kan bidrage til, at en antiepileptisk behandling gennemf $\varnothing$ res.

En del af de psykisk afvigende klienter har begået deres kriminalitet under indflydelse af en psykisk lidelse, der kan være mere eller mindre afløbet ved tilsynsarbejdets påbegyndelse. I sådanne tilfælde vil lægens indsats i selskabet blot blive at konstatere dette gennem en enkelt længerevarende konsultation. Den gruppe psykisk afvigende kriminelle, som på en måde er det st $\varnothing$ rste problem for selskabets psykiatere, består af kleptomane kvinder og sexuelt afvigende mænd.

De kleptomane kvinder kan ofte hjælpes. Deres kriminalitet har en sammenhæng med deres sexualliv i videste forstand. Der kan enten være tale om et resultat af langvarig sexuel skuffelse som f $\varnothing$ lge af egen frigiditet eller andre uheldige ægteskabelige forhold - eller kleptomanien synes at være et udslag af en hormonal balanceforstyrrelse f $\phi \mathrm{r}$ eller i overgangsalderen. Teoretisk skulle disse forhold kunne behandles af en psykoterapeutisk skolet læge med godt resultat, men der er flere praktiske vanskeligheder. Psykoterapi af frigiditet er tidrøvende og burde i perioder foregå indtil 2 gange ugentligt med mindst $1 / 2$ time hver gang, hvilket som regel overstiger kapaciteten. Endvidere har nogle af de kleptomane kvinder vanskeligt ved at indstille sig på en mere eller mindre tvungen behandling. Det drejer sig om socialt veltilpassede kvinder, som er meget ængstelige for at andre skal få noget at vide om deres vilkår eller om kriminaliteten i det hele taget. Her har det været en fordel med de „lukkede" behandlingsdage, hvor klienten er tilsagt på klokkeslet. Venteværelsekontakt med andre undgås, og behandlingen får noget af samme karakter som i en privatkonsultation. Dette i 
forbindelse med at de behandlende læger er specialister medfører efter min mening et fortrin for klienterne frem for hvad der kan tilbydes af andre psykiatriske institutioner.

Noget lignende g $\phi \mathrm{r}$ sig gældende for en stor del af de sexuelt afvigende klienter. Her er det vel ikke altid den „private“ eller „lukkede“ karakter, som er det vigtigste, men denne gruppe er til gengæld karakteriseret af en betydelig grad af generthed og ængstelse. Det er for en hvilken som helst psykiater en meget vanskelig opgave at etablere et terapeutisk forhold til en exhibitionist eller voyeurist. Der skal ikke mange ydre ulemper til i behandlingssituationen $f \varnothing r$ en sådan klient trækker f $\varnothing$ lehornene til sig igen.

Det er i det hele tage noget tvivlsomt, i hvor $h \varnothing j$ grad man aktivt kan helbrede i sexuelle abnormiteter, det her drejer sig om. Undertiden kan det måske gøres i form af en egentlig psykoanalytisk behandling, som der imidlertid ikke er praktisk mulighed for at iværksætte. Der er hverken kvalificerede analytikere eller penge nok.

Det er dog min erfaring at man ved en ihærdig psykoterapi af mere underst $\phi$ ttende (supportativ) karakter kan hjælpe nogle af disse mennesker, men også en sådan terapiform er langvarig og belastende for selskabets lægelige kapacitet.

De pågældende sexuelle afvigelser opfattes af adskillige psykiatere som et resultat af manglende psykisk modenhed. Dette er sikkert rigtigt, men som det ses af tabel 3 drejer det sig ikke om purunge afvigere. Tværtimod er flertallet af vore exhibitionister og voyeurister gifte eller fraskilte, og deres kriminalitet har f $\varnothing$ rst givet sig udslag efter ægteskabets indgåelse. Dette forhold er også iagttaget fra psykoanalytisk side. Den populære antagelse, at man kan håbe på at den sexuelle afvigelse forsvinder, når afvigeren får en heterosexuel partner, deles ikke af selskabets læger. Det er formentlig kun hos de alleryngste og helt uerfarne afvigere, man kan tillade sig at have sådanne forhåbninger. Gennem mit arbejde med disse lovovertrædere har jeg flere gange erfaret, at det kriminelle tilbagefald netop sker i tilslutning til en ægteskabelig konflikt, som den pågældende på grund af sin manglende evne til at hrevde sig får udløsning for gennem et ganske ubevidst og uplanlagt impulsgennembrud af trangen til at kigge eller vise sig frem, som de fleste af os har haft lejlighed til at iagttage hos vore små børn i $2-5$ års alderen. Det har gennem den terapeutiske kontakt af og til været os muligt at se dette og at få klienten til at indse det på en måde, som har været til hjælp.

Et særligt arbejdsområde for selskabets psykiatere er samarbejdet med centralkontorets unders $\phi$ gelsesafdeling, som varetager arbejdet med personunders $\varnothing$ gelserne i henhold til rets- 
plejelovens $\S 800 \mathrm{~A}$. Disse unders $\varnothing$ gelsers værdi $\phi$ ges, hvis de indeholder gode oplysninger om de unders $\varnothing$ gtes helbredsforhold. På opfordring af undersøgerne rekvirerer selskabets læger derfor oplysninger om de unders $\phi$ gte fra hospitaler og kliniker, hvor de tidligere er unders $\phi$ gt og behandlet. Foresp $\phi$ rgslerne bilægges altid en samtykkeerklæring fra den unders $\phi$ gte. Oplysningerne indløber som regel i form af almindelige udskrivningskort eller i form af psykiatriske journaler til låns. Ikke alt, som står i udskrivningskort og journaler, egner sig til afskrift i en personunders $\phi$ gelse, og heller ikke alt er umiddelbart forståeligt for juristerne. Selskabets psykiatere uddrager derfor også af de modtagne oplysninger de relevante forhold, som unders $\varnothing$ geren b $\phi \mathrm{r}$ anf $\phi r e$ i sin rapport.

Personunders $\varnothing$ gelserne skal afsluttes med eventuelle forslag om særvilkår, og undertiden finder unders $\phi$ geren det også hensigtsmæssigt at foreslå en egentlig mentalobservation. Undersøgerne har imidlertid forskellige synspunkter og forudsætninger med henblik på denne del af deres arbejde. Jeg har derfor under mit arbejde for selskabet lagt megen vægt på at udvikle samarbejdet med unders $\varnothing$ gelsesafdelingen, idet jeg forestiller mig, at det kan være af betydelig kriminel præventiv værdi at forslag om særvilkår formuleres på den helt rigtige måde.

Antallet af domme med vilkår om psykiatrisk behandling har været jævnt stigende de senere år. Dette skyldes næppe selskabets psykiatere, men måske snarere en stigende ,terapeutisk“ indstilling hos unders $\varnothing$ gerne. Det er nærmest mit indtryk at psykiaterne virker som en bremse her. Psykiaterne vil i mange tilfælde kunne påpege de praktiske vanskeligheder ved at opnå noget som helst gennem et lægeligt særvilkår.

Ganske den samme opfattelse mener jeg kan gøre sig gældende med henblik på eventuelle forslag i personunders $\phi$ gelserne om mentalobservation. Den stigende optimisme med henblik på psykiatriens muligheder deles visselig ikke altid af psykiaterne i de enkelte tilfælde.

I de tilfælde, hvor psykiateren går ind for, at der $\mathrm{i}$ personunders $\varnothing$ gelsen formuleres et forslag om lægelige særvilkår, betyder psykiaterens medvirken i nogle tilfælde, at det foreslåede vilkår bliver formuleret hensigtsmæssigt. Jeg tænker her på de tilfælde, hvor et alment vilkår om psykiatrisk behandling er langt mindre effektivt end et vilkår om lægelig behandling med mulighed for hospitalsindlæggelse i visse situationer.

Efter mit indtryk lægges der fra unders $\emptyset$ gelsesafdelingens side et meget stort arbejde i personunders $\varnothing$ gelserne, hvoraf der ialt foretages mellem $2 \mathrm{og} 3000 \mathrm{om}$ året i Danmark. Jeg finder det $\phi$ nskeligt, at der skabes $\phi$ konomisk mulighed for at frig $\phi$ re lidt særlig interesseret arbejdskraft til at foretage en systematisk vurdering af dette meget store arbejde. Samtlige unders $\phi$ gelser 
burde i en periode tilrettelægges systematisk med henblik på en senere efterunders $\varnothing$ gelse. Lфsningen af denne opgave må have stor værdi for fremtidens kriminalpræventive virksomhed.

En mindre del af psykiaternes arbejdstid i selskabet er afsat til konference med forsorgsmedarbejderne. Det er mit indtryk, at disse konferencer om enkeltsager er til gensidig berigelse for deltagerne. I andre lande har socialrådgivere, blandt hvilke fremtidens forsorgsmedarbejdere stort set må rekrutteres, mulighed for en særlig uddannelse i ,case-work" — altså i indgående arbejde med enkeltpersoner. Herhjemme savnes en sådan særlig uddannelse. I forsorgsselskabet kunne der bødes noget på denne mangel, hvis der kom yderligere mulighed for en mere systematisk konferencevirksomhed mellem læger og forsorgsmedarbejdere, hvorunder der var tid til ikke alene at drøfte de enkelte sager, men også at drøfte dem gennem længere tid.

I den talmæssige redeg $\varnothing$ relse for selskabets psykiatriske virksomhed er ikke medtaget alle klienter, som psykiaterne har med at gøre. Udeladt er de prøveløsladte, såvel fra statsfængsler som ungdomsfængslet. Også klienter uden vilkår om lægelig behandling viser sig af og til at have brug for samtaler med selskabets læger. I min redeg $\phi$ relse har jeg heller ikke skelnet mellem de betinget d $\varnothing$ mte, pr $\varnothing$ vel $\varnothing$ sladte eller benådede på den ene side og $\S 70$ tilfældene på den anden side. Der har fra enkelt hold været $\phi$ nsker fremme om, at $\S 70$-tilfældene helt og holdent burde henvises til hospitaler og andre bestående helbredsinstitutioner. Som forholdene er nu, vil man gøre de pågældende klienter en dårlig tjeneste herved. De har nøjagtigt samme behov for en særlig interesseret socialpsykiatrisk behandling som selskabets $\phi \mathrm{v}$ rige klienter. Fraset de egentligt sindssyge må man også hævde, at det ofte kan bero på noget nær tilfældigheder, om der bliver iværksat den for en $\S 70$-afg $\phi$ relse n $\phi$ dvendige mentalobservation. Det afhænger af, om kriminaliteten har været stor nok eller om forsvareren har været mere eller mindre ihærdig for at undgå - respektive opnå - mentalobservation.

Som nævnt $\mathbf{i}$ indledningen lader en systematisk vurdering af resultaterne sig ikke gøre. Det skulle imidlertid klart fremgå af min redeg $\phi$ relse, at det psykiatriske arbejde i forsorgsselskabet på en række punkter adskiller sig fra det tilsvarende i hospitalsinstitutioner og i privat praksis.

Hvad alkoholisterne angår aflastes selskabet noget af alkoholkliniken ved justitsministeriets psykiatriske klinik (jvnf. tabel 1). Denne klinik tager principielt helst klienter i behandling, som forinden er mentalobserveret ved kliniken, og dens kapacitet er i det hele taget ikke stor, men til gengæld synes dens 
principper at være de samme som i forsorgsselskabet. Henvisning til de $\phi$ vrige alkoholistkliniker bruges $\mathrm{i}$ det væsentlige kun, hvis klienten i forvejen har haft en længerevarende, positiv tilknytning dertil. Disse kliniker drives efter udprægede frivillighedsprincipper, således at de ikke er indstillet på en behandlingskontrol, som er fast nok i forhold til klientens risiko for kriminelt recidiv. Endvidere er der ofte alt for travlt på disse kliniker.

De $\phi$ vrige psykoterapeutiske opgaver i selskabet $s \varnothing$ ges af og til gennemført gennem henvisning til privat praktiserende psykiatere, som betales af Dansk Forsorgsselskab, der igen får bel $\varnothing$ bet refunderet som delinkventomkostninger. Det er kun få klienter, der på denne måde kan hjælpes, fordi der findes så utroligt få privat praktiserende psykiatere i Danmark.

Enkelte i selskabets ledelse har $\phi$ nsket, at den psykiatriske behandling af selskabets klienter skulle henlægges til bestående psykiatriske polikliniker eller ambulatorier. Noget sådant kan imidlertid ikke gennemf $\varnothing$ res. Hverken inden for Københavns kommunes hospitalsvæsen, på Rigshospitalet, på Frederiksberg hospital eller på Statshospitalet i Glostrup findes der åbne ambulatorier, som kan varetage disse opgaver. Fra statshospitalernes side er der $\phi$ nsker fremme om at udvide disse hospitalers ambulatorievirksomhed meget betydeligt, således at de også bliver i stand til at påtage sig socialpsykiatriske opgaver. Realiseringen af disse $\phi$ nsker henstår imidlertid endnu i det uvisse.

Der er næppe tvivl om, at meget veludbyggede offentlige ambulatorier med konsultation flere gange om ugen - helst efter almindelige menneskers arbejdstid - kunne varetage en meget stor del af den psykiatriske behandling af selskabets klienter. Man må blot ikke tro, at det udelukkende bliver en god ordning for disse. En god ordning ville, som allerede antydet, kræve et intimt samarbejde mellem tilsynsmyndigheden og den behandlende læge. Man kan ikke uden videre regne med, at de socialrådgivere, som søger ind ved hospitalsvæsnet vil have den samme motivering for at gå op i arbejdet med kriminelle som socialrådgiverne ved forsorgsselskabet har det. Man må heller ikke glemme adskillige kriminelle klienters behov for særligt diskrete og personligt prægede behandlingsformer, som ambulatorier med deres venteværelser og skiftende lægepersonale ikke altid kan byde på. Indtil videre må man derfor finde det rigtigst, at forsorgsselskabet henviser klienter uden for København til behandling hos bestemte, faste læger ved statshospitalernes konsultationer og yder dem honorar derfor — netop for at g $\phi$ re behandlingssituationen så personlig som mulig. I Københavnsområdet burde man nok indtil videre stræbe efter at udvide centralkontorets psykiatriske behandlingskapacitet. 
Når man i almindelighed taler om retspsykiatri, tænkes der ofte på den psykiatriske indsats, der går forud for dommen hele tilregneligheds- og strafegnethedssp $\varnothing$ rgsmålet. Man tænker også i nogen grad på det arbejde, der udføres i særfængsel og forvaringsinstitutioner samt på $\S 70$-tilfældenes skæbne.

Derimod tænkes der alt for lidt på, at retspsykiatrien også omfatter det store arbejde med betinget d $\varnothing \mathrm{mte}$, betinget benådede og betinget pr $\varnothing$ vel $\varnothing$ sladte med lægelige særvilkår.

Dansk Forsorgsselskab har den mest centrale position i dette arbejde og den største praktiske erfaring. Min redeg $\varnothing$ relse skal derfor afsluttes med et $\varnothing$ nske om at praktikere fra forsorgsselskabet - også fra dets psykiatriske arbejde - må blive taget med på råd ved tilrettelæggelsen af fremtidens kriminalforsorg. Fini Schulsinger. 